\title{
Mesenchymal tumor in the mantle of the mussel Modiolus difficilis from Amursky Bay in the Sea of Japan
}

\author{
L. N. Usheva*, N. A. Odintsova \\ Institute of Marine Biology, Far East Branch of the Russian Academy of Sciences, Vladivostok 690041, Russia
}

\begin{abstract}
Morphology, cell composition and histochemistry of a gross mantle tumor of Modiolus difficilis are described. The well-differentiated tumor contained numerous cells atypically rich in neutral polysaccharides and bundles of fibrous tissue and muscles. Mitotic activity of the cells of the tumor base ranged from 0 to $0.8 \%$. Architectural disorganization, the presence of collagen and necrotic cells, cellular and nuclear changes, the absence of a protective epithelium and hemocytic infiltration of the tumor base permitted the tumor to develop as a result of chronic irritation and inflammation of the anomalous developing mantle.
\end{abstract}

KEY WORDS: Tumor Proliferation Mitotic index - Mantle $\cdot$ Mussel

\section{INTRODUCTION}

Tumors of Bivalvia have been investigated more extensively than in other invertebrates (Pauley 1969, Khudoley \& Syrenko 1977, Lauckner 1983, Sparks 1985, Mix 1986, Peters 1988, 1994, Pekkarinen 1993). There are some works devoted to the description of external tumors in marine mollusks (Smith 1934, Sparks et al. 1964, 1969, Pauley \& Sayce 1968, Pauley 1969, Dix 1972, Dinamani \& Wolf 1973, Harschbarger 1976, and others). External tumors in mollusks of the Far East Region have not been previously reported. We have examined some bivalve species common in the Sea of Japan from a bay near Vladivostok to estimate the frequency of tumor occurrence. The purpose of this work is to describe the microanatomy, cell composition and histochemistry of a large polypoid tumor in the mantle of the mussel Modiolus difficilis and to interpret its nature.

\section{MATERIALS AND METHODS}

In May 1989, 60 mussels Modiolus difficilis were collected from Amursky Bay, Sea of Japan, within the

·E-mail: aisa@gin.global-one.ru city precincts of Vladivostok, in Vtoraya Rechka Inlet, an area intensively polluted by industrial and domestic sewage. One external tumor was found. The tumor was excised and fixed in phosphate buffered $10 \%$ neutral formalin ( $\mathrm{pH} 7.3$ to 7.4 ), containing $3 \% \mathrm{NaCl}$, for $36 \mathrm{~h}$ at $4^{\circ} \mathrm{C}$. Samples were gradually dehydrated and embedded in polyethylene glycol 3000 (Efimov 1984). Sections 4 to $5 \mu \mathrm{m}$ thick were stained with either Mayer's hematoxylin and eosin (H\&E), methylene blue, Heidenhain's azan, Van Gison's stain, Giemsa stain, period acid-Schiff (PAS) reactive-alcian blue-hematoxylin, Feulgen staining, or fast green (Lillie 1965, Pearse 1968). The mitotic index (MI) was determined in 2 zones of the tumor base and in the protective epithelium after examination of 10 tumor sections. The MI was calculated per 170000 tumor cells of the first zone, per 42000 tumor cells of the second zone and per 10000 cells of protective epithelium, respectively.

\section{RESULTS}

One large pink polypoid growth was found on the mantle near the adductor muscle of a mussel $12 \mathrm{~cm}$ in shell length (Fig. 1). The growth was of a solid consistency, was non-pedunculated, measured $15 \mathrm{~mm}$ in 


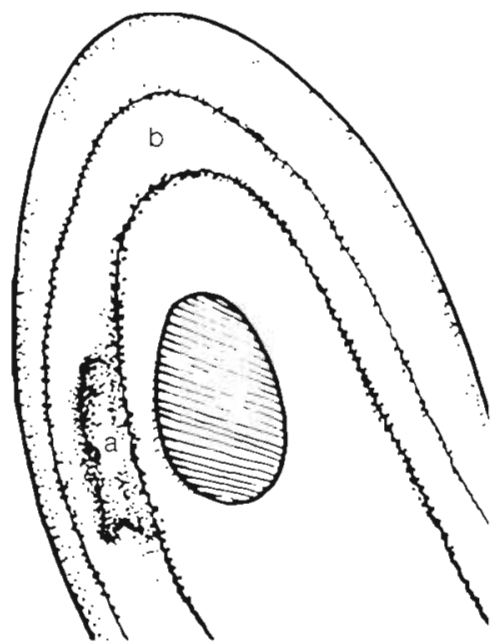

Fig. 1. Modiolus difficilis. Location of a polypoid tumor (a) on the mantle (b) of the mussel

length and was $4 \mathrm{~mm}$ thick. Distinctive portions of the structure were observed (Fig. 2, a-e). The tumor surface was covered by a single-layered columnar ciliated epithelium with associated gland cells (granular eosinophilic cells with proteins, agranular basophilic cells with glucosaminoglycans and fuchsinophilic cells with neutral polysaccharides). Parts of the tumor protective epithelium were absent because of destruction and sloughing (Fig. 2, c-e). We found atypical portions of the protective epithelium: non-convoluted low columnar or cuboidal epithelium on the left side of the tumor body (Fig. 2, d), deeply convoluted epithelıum at the top of the tumor and epithelium at the base of the tumor with some mitotic cells and cells with clearly marginated transparent nuclei and large conspicuous nucleoli (Fig. 3).

The outer part of the tumor base consisted of smooth muscular and collagen fibers and some connective tissue cells. Three small bundles of longitudinal muscular and collagen fibers originated from the base and ran to the top (Fig 2, b) The inner central part of the tumor base (zone I with a slight hemocytic infiltration) was not fibrillar and consisted mainly of cells with a thin-granular cytoplasm and normal vessels. The marginal right side of the tumor base (zone II with a strong hemocytic infiltration) was located under the epithelium and was rich in hemal sinuses, granular eosinophilic and hyaline hemocytes, some minute hemocytes with basophilic nuclei and some atypical hemocytes with abnormal gross nucleus (Fig. 4).

Undifferentiated small cells with basophilic cytoplasm, with large basophilic rounded or oval nuclei and not always noticeable nucleoli, were found in the tumor base. Mitoses were found in cells of different sizes (Figs. $5 \& 6$ ), but mainly in small cells. The cyto-
Fig. 2. Modiolus difficilis. Schematic representation of the mantle tumor on a longitudinal section. The portions of the tumor: (a) base, (b) body, (c) top with sloughing area. (d) The left side tumor body (dots) consists of low prismatic epithelium; (e) the right side of tumor consists of muscles and detached covering epithelium. (f) Vessel-like tubules. (g) Muscular and collagen fibers. (h) Location of large granular epithelial gland cells

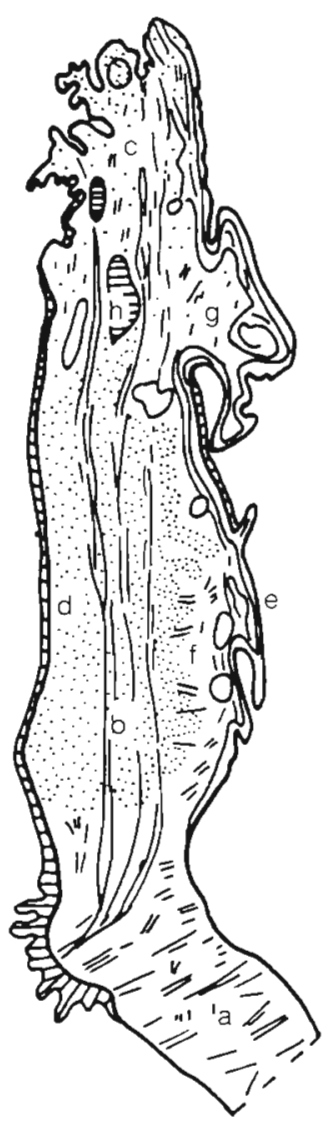

plasm of mitotic cells usually lacked inclusions, but some large mitotic cells had a granular cytoplasm resembling that of tumor cells. Some mitotic binucleate cells and abnormal mitoses were found. Average mitotic activity in tumor cells was $0.015 \%$ in zone I and $0.026 \%$ in zone II of the entire tumor base. The overall MI range of the tumor cells of several tumor sections was 0 to $0.8 \%$. The MI of protective epithelial cells was $0.26 \%$, and focal concentrations of mitoses in some tumor sections examined were as much as $2 \%$. Prophases prevailed ( $50 \%$ ) among mitotic tumor cells, whereas meta- and anaphases were most numerous $(75 \%)$ among mitotic epithelial cells (Figs. $3 \& 5$ ).

The major part of the tumor consisted of cells with a fine granular cytoplasm (Fig 7). The tumor cells were intensively stained blue with methylene blue or with Giemsa stain and formed compact accumulations near vessel-like tubules (Fig. 8). They were stained red or lilac with Heidenhain's azan, or pale yellow with Van Gison's stain. Cells containing proteins were atypically rich in neutral polysaccharides and glycogen, whereas cells of the tumor top and base had small amounts of neutral polysaccharides (Figs. 9 to 11). The tumor cells were pleomorphic with a strongly marked nuclear polymorphism. Cells were revealed which contained heterochromatic and large nuclei and nucleoli, micro- 
3

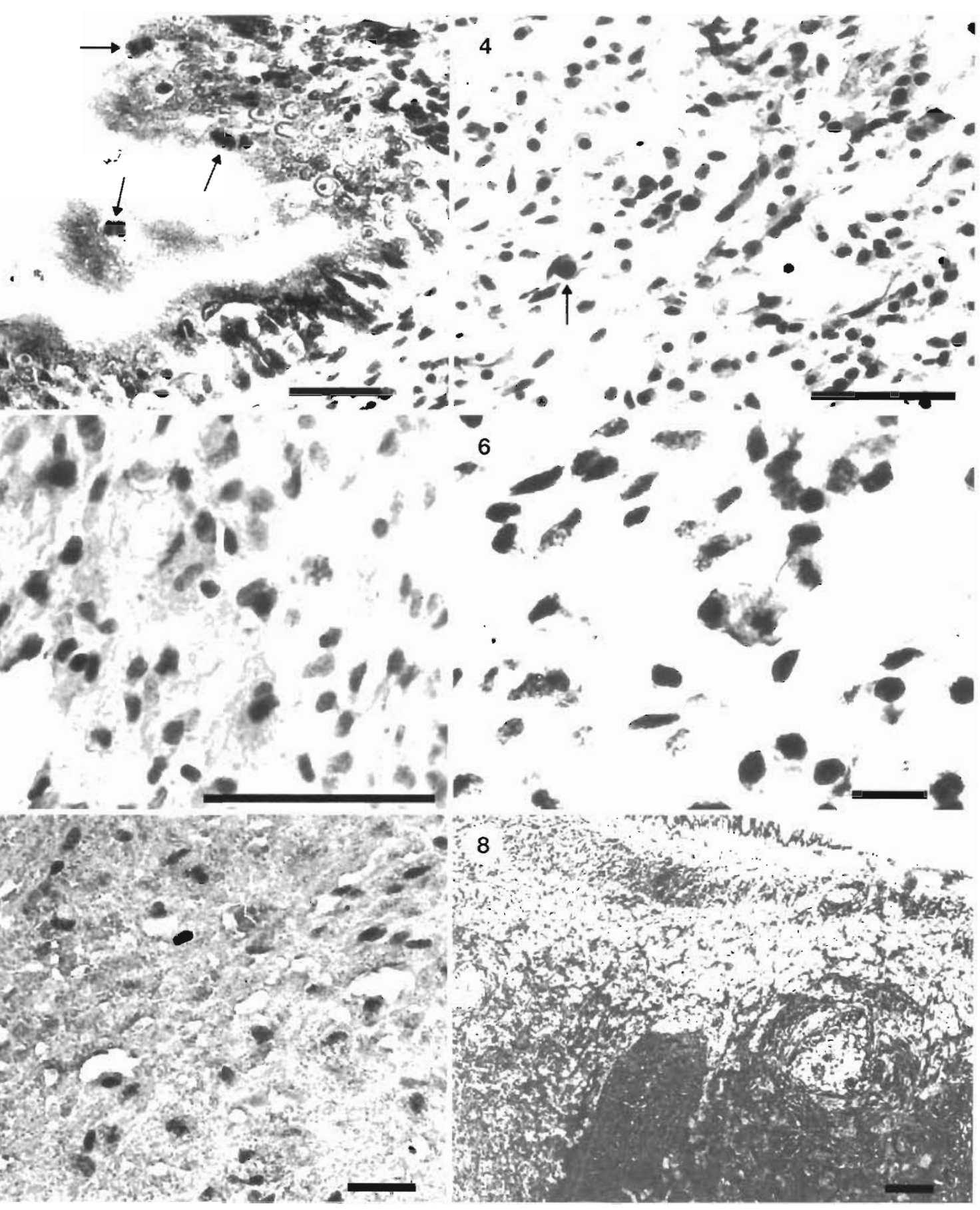

Figs. 3 to 8. Modiolus difficilis. Histological structure of mantle polypoid tumor. Fig. 3. Covering epithelium of the tumor base with mitotic cells (arrows) and cells with marginated transparent nuclei and conspicuous nucleoli. H\&E. Scale bar $=50 \mu \mathrm{m}$. Fig. 4. Cells of the tumor base in zone II (strong hemocytic infiltration and atypical large nuclei) (arrow) H\&E. Scale bar $=50 \mu m$ Fig. 5. Prophase in small cells of the tumor base. Scale bar $=50 \mu \mathrm{m}$. Fig. 6. Gross telophase in hemal sinus. H\&E. Scale bar $=$ $\overline{10 \mu \mathrm{m}}$. Fig. 7. Cells of the tumor body with a granular cytoplasm. Scale bar $=50 \mu \mathrm{m}$. H\&E. Fig. 8. Accumulations of intensively stained tumor body cells near vessel-like tubules. Giemsa stain. Scale bar $=100 \mu \mathrm{m}$

nuclei and chromatin clamps in cytoplasm, fragments of the chromosome bridge, and different Feulgenstained nuclei (Fig. 12). Undifferentiated small cells (with large basophilic nuclei and small nucleoli) were rare in the major portion of the tumor, with only 2 normal and 1 abnormal mitoses (anaphase with lagging chromosomes) observed here, whereas 64 mitoses were found at the tumor base. The outer right side of 


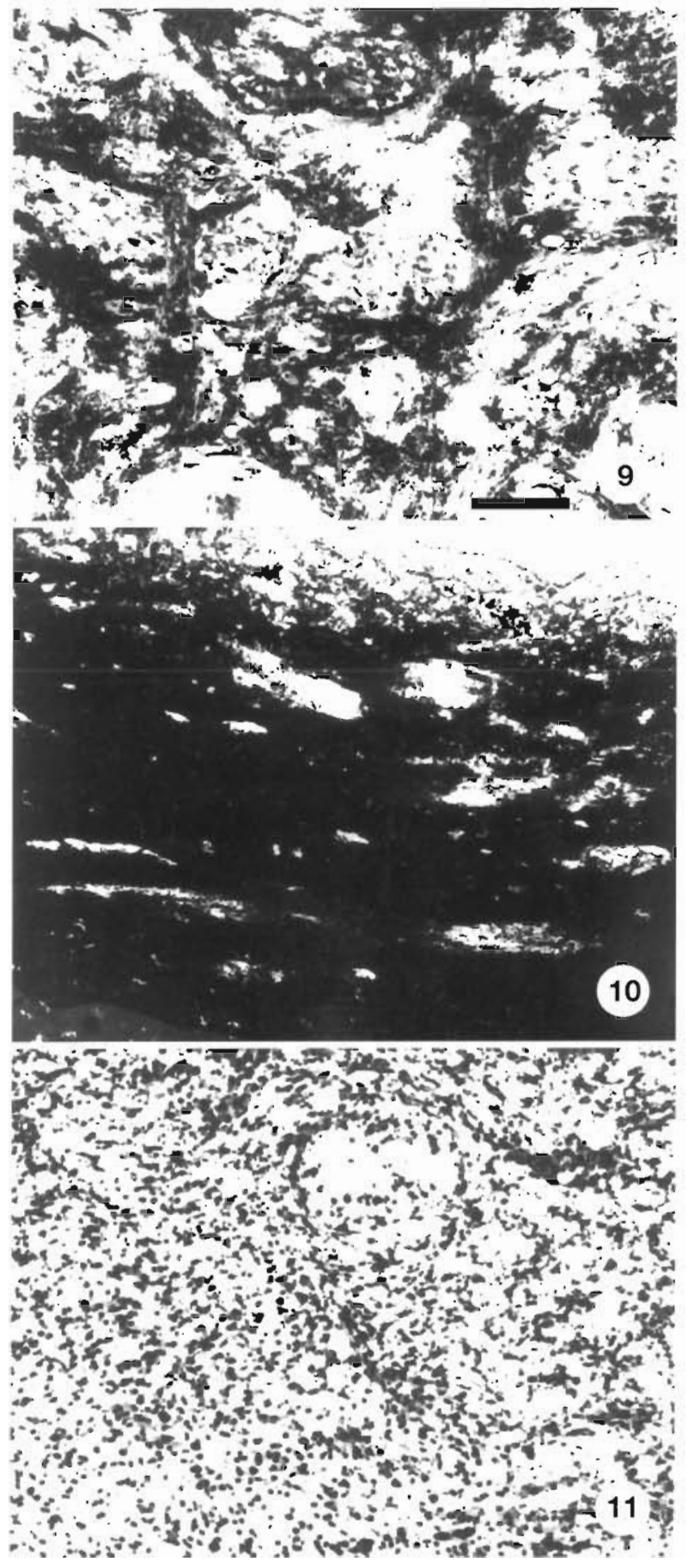

Figs. 9 to 11 Modiolus difficlls. Portions of the tumor (Fig. 9, top; Fig. 10, body; Fig. 11, base near tumor body) containing different amounts of the neutral polysaccharides. PAShematoxylin. Scale bar $=100 \mu \mathrm{m}$

the growth was fibrous and showed a weak hemocytic infiltration. It consisted of a muscular layer and collagen. A clear atrophy and destruction of muscle cells and subepithelial gland cells were found (Fig. 13).
The top of the tumor consisted mainly of muscles in a collagen matrix and collagen fibers. Atrophy and necrosis of muscular fibers were distinct; areas of necrotic tissue and cells with lipofuscin were found. The external portion of the top was ulcerated and had a fringe-like edge, because some large pieces of tissue were sloughing Large areas of subepithelial atypical gland cells with large metachromatically colored granules were present (Fig. 2, h). Some vessel-like tubules, surrounded by tumor cells and collagen were found (Figs. 2, f, \& 14). Vacuolized cells with diffuse PASpositive material, some tumor cells with eosinophilic grains, rare normal hemocytes and cells with lipofuscin were revealed inside. No mitoses or undifferentiated cells were found in the apical aspect of the tumor.

\section{DISCUSSION}

We classified the large polypoid growth on the mussel mantle as a mesenchymal benign tumor, and not as a teratoma or a malignant tumor. The growth originated from multiple locations in the mantle tissue, did not produce metastasised tissues and was characterized by architectural disorganization and pattern atypia rather than by similarity with a normal mantle. The cell pattern consisted of well-differentiated cells and did not resemble that of other mesenchymal tumors of Bivalvia (Smith 1934, Sparks et al. 1964 1969, Pauley 1969, Dix 1972, Dinamani \& Wolf 1973 Harschbarger 1976, Sparks 1985)

We distinguished in the tumor bulk several kinds of fine granular cells, atypical for normal mussel mantle. Some of them were myocytes (positive staining with Van Gison's stain, Heidenhain's azan and fast green). Others appeared to be connective-tissue cells and differed morphologically from normal mantle storing cells. A third group appeared to be modified hemocytes, because they were colored as intensively with Giemsa stain (Fig. 8) as the hyaline hemocytes of mussels were (Rasmussen et al. 1985). Unlike normal mussel hemocytes (Moore \& Loowe 1977) and tumor base cells, all tumor cells types had an abnormally high content of neutral polysaccharides and glycogen.

Similar to other mesenchymal molluscan tumors (Sparks 1985), undifferentiated and mitotic cells were found rarely in the tumor body. However, undifferentiated cells were observed more often in the base portion of the tumor. Mitotic activity in the cells of this portion greatly exceeded that observed in the tumor body cells, but did not reach the average level of mitotic activity which occurs in cells of molluscan mature disseminated neoplasias or of normal renewing and regenerating tissues (Hillman 1963, Usheva \& Leibson 1988, Reno et al. 1994\}. The MI of the tumor base cells 


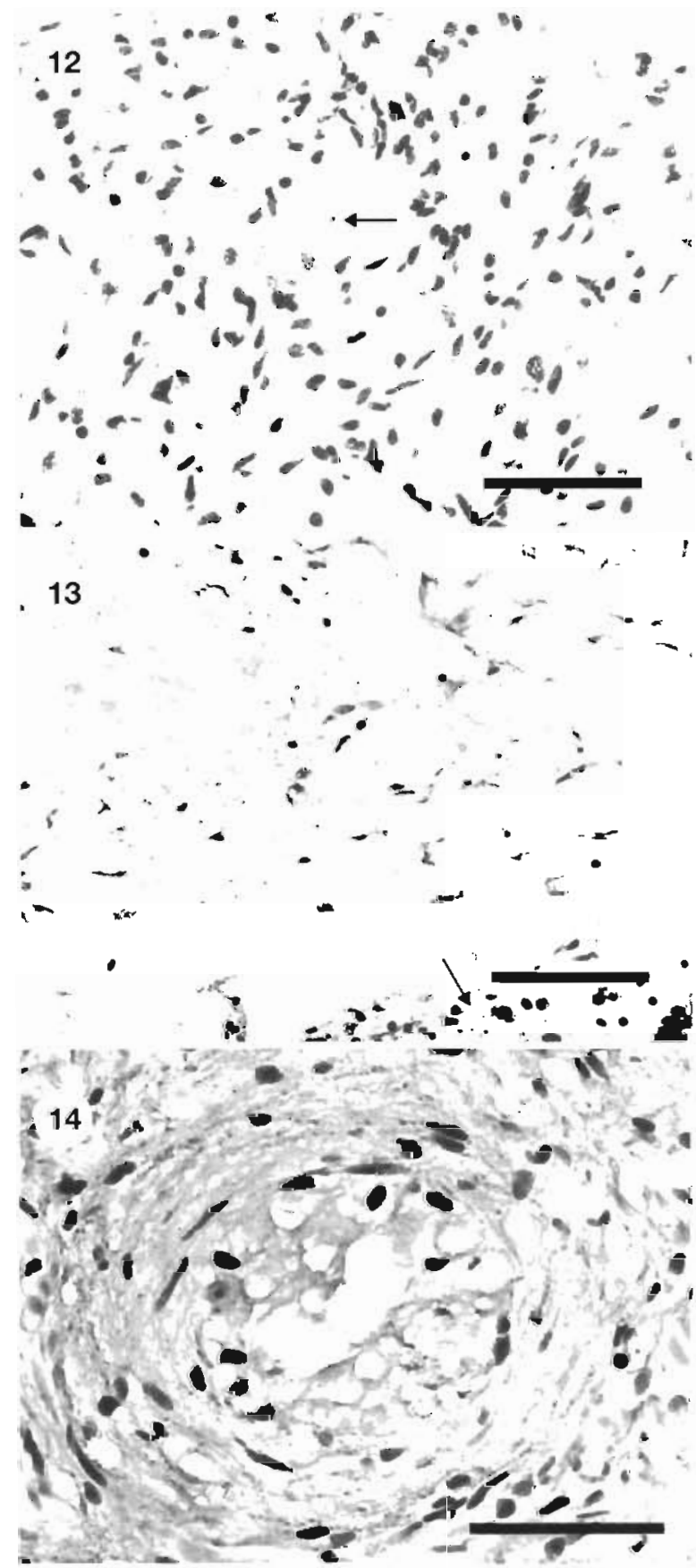

Figs. 12 to 14. Modius difficilis. Histological structure of mantle polypoid tumor. Fig. 12. Nuclei polymorphism of tumor cells; one can see nuclei of different shapes, sizes and staining intensity, micronuclei (arrow). Feulgen stain. Scale bar = $100 \mu \mathrm{m}$. Fig. 13. Right side of the tumor with necrotic covering epithelium (arrow) and muscle fibers. H\&E. Scale bar = $100 \mu \mathrm{m}$. Fig. 14. Vessel-like tubules with vacuolized tumor cells. H\&E. Scale bar $=100 \mu \mathrm{m}$

ranged from 0.01 to $0.03 \%$ and was highest in the zone of strong hemocytic infiltration. Both undifferentiated cells and hemocytes may perhaps proliferate here, and the former became differentiated as cells of the fibroblast line. As they grew, cells protruded outward from the mantle, were modified and formed the tumor bulk. The MI of protective epithelium cells was an order higher $(0.3 \%)$ than that of tumor base cells and comparable with that of normal renewing and regenerating molluscan tissues (Hillman 1963, Usheva \& Leibson 1988). This high mitotic level seems to be related to an inflammation of the mussel mantle. The covering epithelium of the growth seemed to be in a state of regeneration.

Signs of inflammation of the covering epithelium and some tumor parts under the epithelium were found both in the Modiolus difficilis tumor and in other mesenchymal molluscan tumors (Sparks et al. 1964, 1969, Pauley 1969, Dix 1972, Dinamani \& Wolf 1973, Harschbarger 1976, Sparks 1985). However, we found an unusual pattern of inflammation in the $M$. difficilis tumor: hemocytic infiltration and cell reproduction occurred mainly in the tumor base whereas a clear atrophy, a marked destruction of muscular tissue and collagen formation were observed on the top and in the right portions. Muscle atrophy may have been related to nutrient destruction, and the vessel-like tubules with thickened walls may have developed as a result of chronic inflammation of normal vessels. These structures did not resemble the pseudotubes or rosettelike structures found in oyster mesenchymal tumors (Sparks et al. 1969), but were similar to pathological vascular vessels of diseased mollusks Mya arenaria (Barry et al. 1971). Mantle vessel-like tubules had tumor cells whereas these cells were not found in normal vessels of the tumor base. The cells of the vessellike tubules seem to be modified hemocytes and/or endothelial cells.

These facts permit the supposition that a mantle tumor in Modiolus difficilis had developed due to inflammation and chronic irritation caused by an unknown agent. Destruction, cell sloughing, detachment of necrotic flaps from the top of the tumor, partial ulceration and deep invaginations of the covering epithelium suggest protracted irritation of this tumor. We assume that the irritant had a viral or chemical nature, taking into account the fact that the mollusks examined were collected from the polluted inlet of Amursky Bay where some Bivalvia have even become extinct (Tkalin et al. 1993, Silina \& Ovsyanikova 1995). The cytogenetic anomalies of the interphase and mitotic cells seem to be related more to the influence of the pollutants than to dysplasia-like changes of tissues and result in a breakdown of cell homeostasis. The same cytogenetic anomalies associated with the polluted environment were observed in the larvae of marine animals (Klumpp \& von Westernhagen 1995). 
Thus, the mussel mantle tumor was characterized as an unusual pattern of fibromyoma in a state of irritation. Cell proliferation was mainly observed in the base of the tumor, whereas the detachment of flaps was found at the top of the tumor.

\section{LITERATURE CITED}

Barry MM, Yevich PP, Thayer NH (1971) Atypical hyperplasia in the soft-shell clam Mya arenaria. J Invertebr Pathol $17: 17-27$

Dinamani P. Wolf PH (1973) Multiple tumors in the pericardial cavity of an Australian rock oyster (rassostrea commercialis (Iredale and RoughIy). Int J Cancer 11:293-299

Dix TG (1972) Two mesenchymal tumors in a pearl. oyster Pinctada margaritifera. J Invertebr Pathol 20:317-320

Efimov IA (1984) A. new embedding medium for making histological preparations. Tsitologia 26:1331-1332 (in Russian)

Harshbarger JK (1976) Description of polyps and epidermal papillomas in three bivalve mollusk species. Mar Fish Rev $38(10): 25-29$

Hillman RE (1963) An observation of the occurrence of mitosis in regenerating mantle epithelium of the eastern oyster Crassostrea virginica. Chesapeake Sci 4:172-174

Khudoley VV, Syrenko OA (1977) Tumors in mollusks. Adv Mod Biol 84:128-137 (in Russian)

Klumpp DW, von Westernhagen $H$ (1995) Biological effects of pollutants in Australian tropical coastal waters: embryonic malformations and chromosomal aberrations in developing fish eggs. Mar Poll Bull 30(2):58-166

Lauckner G (1983) Diseases of Mollusca: Bivalvia. Abnormalities. Neoplasia. In: Kinne $O$ (ed) Diseases of marine animals, Vol. Il. Biologische Anstalt Helgoland, Hamburg, p 848-963

Lillie RD (1965) Histopathologic technic and practical histochemistry. McGraw-Hill, New York, p 456-516

Mix MC (1986) Cancerous diseases in aquatic animals and their association with environmental pollutants: a critical literature review. Mar Environ Res 20:1-141

Moore MN, Lowe DM (1977) The cytology and cytochemistry of the hemocytes of Mytilus edulis and their responses to experimentally injected carbon particles. J Invertebr Pathol 29:18-30
Pauley GB (1969) A critical review of neoplasia and tumorlike lesions in molluscs. In: Neoplasms and related disorders in invertebrates and lower vertebrate animals, Vol 31 Nat Cancer Inst Monogr, New York, p 509-539

Pauley GB Sayce CS (1968) An internal fibrous tumor un a Pacific oyster Crassostrea gigas. J Invertebr Pathol 10:1-8

Pearse AGE (1968) Histochemistry. Theoretical and applied. Little, Brown and Co., Boston, p 171-259

Pekkarinen M (1993) Neoplastic diseases in the Baltic Macoma baltica (Bivalvia) of the Finnish coast. J Invertebr Pathol 61:138-146

Peters EC (1988) Recent investigations on the disseminated sarcomas of marine bivalve molluscs. Am Fish Soc Spec Publ 18:74-92

Peters EC (1994) Comparative histopathology of gonadal neoplasms in marine bivalve molluscs. Dis Aquat Org 20: $59-76$

Rasmussen LPD, Hage E, Karlos O (1985) An electron microscope study of the circulating leukocytes of the marine mussel Mytilus edulis. J Invertebr Pathol 45:158-167

Reno PW, House M, Illingworth F (1994) Flow cytometric and chromosome analysis of soft-shell clams Mya arenaria with disseminated neoplasia. J Invertebr Pathol 64: $163-172$

Silina AV, Ovsyanikova II (1.995) Long-term changes in the community of Japanese scallop and its epibionts in the polluted area of Amursky Bay, the Sea of Japan. Biol Moria 21(1):59-66 (in Russian)

Smith GM (1934) A mesenchymal tumor in an oyster (Ostrea virginical. Am J Cancer 22:838-841

Sparks AK (1985) Synopsis of invertebrate pathology. Exclusive of insects. Elsevier Science, Amsterdam

Sparks AK, Pauley GB, Bates RR, Sayse CS (1964) A mesenchymal tumor in a Pacific oyster Crassostrea gigas (Thunberg). J Insect Pathol 6:448-452

Sparks AK, Pauley GB, Chew KK (1969) A second mesenchymal tumor from a Pacific oyster (Crassostrea gigas). Proc Natn Shellfish Assoc 59:35-39

Tkalin AV, Belann TA, Shapovalov EN (1993) The state of the marine environment near Vladivostok, Russia. Mar Pollut Bull 26(8):418-422

Usheva LN, Leibson NL (1988) Mitotic cycle of cell of the intestinal epithelium from scallop Mizuchopecten yessoensis. Tsitologia 30:554-558 (in Russian)

Manuscript first received: January 23, 1995

Revised version accepted: January 28, 1997
Responsible Subject Editor: A. K. Sparks, Seattle, Washington, USA. 